\section{National HIV Testing Day - June 27, 2019}

National HIV Testing Day, observed each year on June 27, highlights the importance of testing in detecting, treating, and preventing human immunodeficiency virus (HIV) infection. Early diagnosis is critical to controlling HIV transmission in the United States (1). With the aim of reducing the number of new infections in the United States by $90 \%$ in 10 years, the Ending the HIV Epidemic initiative initially will focus on the 50 local jurisdictions where approximately half of diagnoses made in 2016 and 2017 were concentrated and in seven states with a disproportionate occurrence of HIV in rural areas (2). An analysis of 2016 and 2017 populationbased survey data reported in this issue of $M M W R$ found that overall, $38.9 \%$ of the U.S. population had ever tested for HIV infection, including $46.9 \%$ in the 50 local jurisdictions with the majority of diagnoses and $35.5 \%$ in the seven states with disproportionate occurrence of HIV in rural areas. To control HIV transmission, health care providers and public health practitioners need to develop HIV testing strategies to reach segments of the population that have never tested for HIV infection and offer at least annual testing of persons at risk for infection.

Additional information on National HIV Testing Day is available at https://www.cdc.gov/features/HIVtesting. Basic testing information for the public is available at https://www. cdc.gov/hiv/basics/testing.html. Additional information on HIV testing for health professionals is available at https:// www.cdc.gov/hiv/testing. CDC's guidelines for HIV testing of serum and plasma specimens are available at https://www. cdc.gov/hiv/guidelines/testing.html.

\section{References}

1. Li Z, Purcell DW, Sansom SL, Hayes D, Hall HI. Vital signs: HIV transmission along the continuum of care-United States, 2016. MMWR Morb Mortal Wkly Rep 2019;68:267-72. https://doi. org/10.15585/mmwr.mm6811e1

2. Pitasi MA, Delaney KP, Brooks JT, et al. HIV testing in 50 local jurisdictions accounting for the majority of new HIV diagnoses and seven states with disproportionate occurrence of HIV in rural areas, 2016-2017. MMWR Morb Mortal Wkly Rep 2019;68:561-7.

\section{HIV Testing in $\mathbf{5 0}$ Local Jurisdictions Accounting for the Majority of New HIV Diagnoses and Seven States with Disproportionate Occurrence of HIV in Rural Areas, 2016-2017}

\author{
Marc A. Pitasi, $\mathrm{MPH}^{1}$; Kevin P. Delaney, $\mathrm{PhD}^{1}$; John T. Brooks, $\mathrm{MD}^{1}$; \\ Elizabeth A. DiNenno, $\mathrm{PhD}^{1}$; Shacara D. Johnson, $\mathrm{MSPH}^{1}$; \\ Joseph Prejean, $\mathrm{PhD}^{1}$
}

Since 2006, CDC has recommended universal screening for human immunodeficiency virus (HIV) infection at least once in health care settings and at least annual rescreening of persons at increased risk for infection $(1,2)$, but data from national surveys and HIV surveillance demonstrate that these recommendations have not been fully implemented $(3,4)$. The national Ending the HIV Epidemic initiative* is intended to reduce the number of new infections by $90 \%$ from 2020 to 2030 . The initiative focuses first on 50 local jurisdictions (48 counties, the District of Columbia, and San Juan, Puerto Rico) where the majority of new diagnoses of HIV infection in 2016 and 2017 were concentrated and seven states with a disproportionate occurrence of HIV in rural areas relative to other states (i.e., states with at least 75 reported HIV diagnoses in rural areas that accounted for $\geq 10 \%$ of all diagnoses in the state). ${ }^{\dagger}$ This initial geographic

\footnotetext{
*https://www.hiv.gov/federal-response/ending-the-hiv-epidemic/overview.

$\dagger$ The 50 local jurisdictions and seven states were identified from diagnoses made during 2016-2017 reported to CDC's National HIV Surveillance System through June 2018. Diagnosis data from 2017 were considered preliminary (https://files.hiv.gov/s3fs-public/ending-the-hiv-epidemic-flyer.pdf). A list of the 50 local jurisdictions and seven states is available in Table 2 of this report and at https://files.hiv.gov/s3fs-public/Ending-the-HIV-Epidemic-Countiesand-Territories.pdf.
}

\section{INSIDE}

568 Cryptosporidiosis Outbreaks — United States, 2009-2017

573 QuickStats

Continuing Education examination available at https://www.cdc.gov/mmwr/cme/conted_info.html\#weekly.

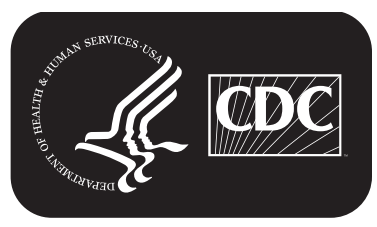


focus will be followed by wider implementation of the initiative within the United States. An important goal of the initiative is the timely identification of all persons with HIV infection as soon as possible after infection (5). CDC analyzed data from the Behavioral Risk Factor Surveillance System (BRFSS) ${ }^{\S}$ to assess the percentage of adults tested for HIV in the United States nationwide (38.9\%), in the 50 local jurisdictions (46.9\%), and in the seven states (35.5\%). Testing percentages varied widely by jurisdiction but were suboptimal and generally low in jurisdictions with low rates of diagnosis of HIV infection. To achieve national goals and end the HIV epidemic in the United States, strategies must be tailored to meet local needs. Novel screening approaches might be needed to reach segments of the population that have never been tested for HIV.

BRFSS is an annual cellular and landline telephone survey of the noninstitutionalized U.S. population aged $\geq 18$ years. The median response rate among all participating states and territories was $47.1 \%$ (range $=30.7 \%-65.0 \%$ ) in $2016^{\circ}$ and $45.9 \%$ (range $=30.6 \%-64.1 \%$ ) in 2017. ${ }^{* *}$ Respondents were asked whether they had ever been tested for HIV outside of blood donation; those who answered "yes" were asked for the month and year of their most recent test. Respondents were also asked whether any of the following HIV risk-related situations applied to them in the past year: injected drugs that were not prescribed, received treatment for a sexually

\footnotetext{
$\$$ https://www.cdc.gov/brfss/index.html.

https://www.cdc.gov/brfss/annual_da101278ta/2016/pdf/2016-sdqr.pdf.

** https://www.cdc.gov/brfss/annual_data/2017/pdf/2017-sdqr-508.pdf.
}

transmitted disease, exchanged money or drugs for sex, had anal sex without a condom, or had four or more sex partners. Those who answered "yes" to this question were considered to have reported recent HIV risk.

Data collected in 2016 and 2017 were pooled and used to estimate the percentage and corresponding $95 \%$ confidence intervals (CIs) of ever testing for HIV and testing for HIV in the past year overall and for each of the 57 jurisdictions. Nationally and within the seven states with disproportionate rural HIV occurrence, counties were grouped as either mostly urban or mostly or completely rural according to designation by the 2010 U.S. Census. ${ }^{\dagger \dagger}$ Rao-Scott chi-square tests were used to compare testing percentages between mostly urban and mostly or completely rural areas in the United States and in the seven states with disproportionate rural HIV occurrence. All estimates were weighted to account for the complex multistage sampling design. HIV diagnosis rates per 100,000 population among persons aged $\geq 13$ years were calculated from HIV diagnoses reported to CDC's National HIV Surveillance System during 2016-2017 through December 2018; U.S. Census population estimates for 2016 and 2017 were used for the denominators. HIV diagnosis rates and testing percentages were examined together for each of the 50 local jurisdictions as well as urban and rural areas of the seven states to further characterize these areas with respect to their current HIV

\footnotetext{
$\dagger_{\dagger}$ https://www.census.gov/programs-surveys/geography/guidance/geo-areas/ urban-rural.html.
}

The MMWR series of publications is published by the Center for Surveillance, Epidemiology, and Laboratory Services, Centers for Disease Control and Prevention (CDC), U.S. Department of Health and Human Services, Atlanta, GA 30329-4027.

Suggested citation: [Author names; first three, then et al., if more than six.] [Report title]. MMWR Morb Mortal Wkly Rep 2019;68: [inclusive page numbers]

\section{Centers for Disease Control and Prevention \\ Robert R. Redfield, MD, Director \\ Anne Schuchat, MD, Principal Deputy Director \\ Chesley L. Richards, MD, MPH, Deputy Director for Public Health Science and Surveillance \\ Rebecca Bunnell, PhD, MEd, Director, Office of Science \\ Barbara Ellis, PhD, MS, Acting Director, Office of Science Quality, Office of Science \\ Michael F. Iademarco, MD, MPH, Director, Center for Surveillance, Epidemiology, and Laboratory Services}

MMWR Editorial and Production Staff (Weekly)

\begin{abstract}
Jacqueline Gindler, MD, Editor
Mary Dott, MD, MPH, Online Editor

Terisa F. Rutledge, Managing Editor Technical Writer-Editors

Matthew L. Boulton, MD, MPH Virginia A. Caine, MD

Katherine Lyon Daniel, PhD

Jonathan E. Fielding, MD, MPH, MBA

David W. Fleming, MD

William E. Halperin, MD, DrPH, MPH
\end{abstract}

Charlotte K. Kent, PhD, MPH, Editor in Chief

Douglas W. Weatherwax, Lead Technical Writer-Editor

Glenn Damon, Soumya Dunworth, PhD, Teresa M. Hood, MS
MMWR Editorial Board Timothy F. Jones, MD, Chairman Robin Ikeda, MD, MPH Phyllis Meadows, $\mathrm{PhD}, \mathrm{MSN}, \mathrm{RN}$ Jewel Mullen, MD, MPH, MPA Jeff Niederdeppe, $\mathrm{PhD}$ Patricia Quinlisk, MD, MPH
Martha F. Boyd, Lead Visual Information Specialist Maureen A. Leahy, Julia C. Martinroe, Stephen R. Spriggs, Tong Yang, Visual Information Specialists Quang M. Doan, MBA, Phyllis H. King, Terraye M. Starr, Moua Yang, Information Technology Specialists
Stephen C. Redd, MD

Patrick L. Remington, MD, MPH

Carlos Roig, MS, MA

William Schaffner, MD

Morgan Bobb Swanson, BS 
morbidity and testing coverage; Pearson's correlation coefficient was used to assess the correlation between these areas' testing percentages and HIV diagnosis rates. Although BRFSS testing percentages were calculated among those aged $\geq 18$ years, HIV diagnosis rates were calculated among those aged $\geq 13$ years to be consistent with methodology used to identify the jurisdictions accounting for the majority of new HIV diagnoses and because of limited availability of single-year age population estimates at the municipio (county equivalent) level in Puerto Rico. Analyses were performed using SAS (version 9.4; SAS Institute) and SUDAAN (version 11.0; RTI International).

During 2016-2017, 38.9\% of adults aged $\geq 18$ years in the United States had ever been tested for HIV (Table 1). Among 15,701 (3.2\%) persons with reported recent HIV risk for whom at least annual rescreening is recommended, $64.8 \%$ were ever tested, and $29.2 \%$ were tested in the past year. Among all adults, the percentage ever tested (46.9\%) was higher among residents of the 50 local jurisdictions that accounted for the majority of diagnoses of HIV infection among persons aged $\geq 13$ years than was the percentage ever tested $(35.5 \%)$ in the seven states with disproportionate rural HIV occurrence. Among persons with reported HIV risk, the percentage tested in the past year (34.3\%) in the 50 local jurisdictions was also higher than that in the seven states (26.2\%). Among all adults in these seven states, $32.1 \%$ of those residing in mostly rural areas and $37.2 \%$ of those residing in mostly urban areas had ever been tested. Among persons with reported HIV risk in these states, $18.4 \%$ of those residing in rural areas and $29.0 \%$ of those residing in urban areas were tested in the past year.
Testing percentages varied widely by jurisdiction (Table 2). Among the 50 local jurisdictions, the percentage of persons aged $\geq 18$ years ever tested ranged from $36.5 \%$ in Maricopa County, Arizona, to $70.7 \%$ in the District of Columbia; the percentage tested in the past year (independent of reported recent HIV risk) ranged from $8.1 \%$ in Alameda County, California, to $31.3 \%$ in Bronx County, New York. Testing percentages were generally low in both urban and rural areas of the seven states with disproportionate rural HIV occurrence. Among the 50 local jurisdictions and seven states, the percentage of persons aged $\geq 18$ years ever tested for HIV generally increased with increasing HIV diagnosis rate among persons aged $\geq 13$ years $(r=0.71 ; p<0.01)$ (Figure). Most of the 50 local jurisdictions had higher testing percentages and diagnosis rates than did the seven states.

\section{Discussion}

In this analysis, $<40 \%$ of the U.S. adult population had ever been tested for HIV. Jurisdictions with the highest rates of diagnosis of HIV infection among persons aged $\geq 13$ years generally had higher testing percentages. The converse was also true. Ever testing for HIV was lower in rural areas of the seven states with disproportionate rural HIV occurrence, compared with that in urban areas of these states, the 50 local jurisdictions with the majority of diagnoses of HIV infection, and the United States nationally. Although past-year HIV testing was higher among persons with reported recent HIV risk than among those without such risk, the percentage tested in the past year was far below the $100 \%$ coverage recommended for this group $(1,2)$. These findings demonstrate missed opportunities

TABLE 1. Ever and past-year testing for human immunodeficiency virus (HIV) among adults aged $\geq 18$ years, by urban-rural classification* Behavioral Risk Factor Surveillance System, United States, 50 local jurisdictions and seven states, ${ }^{\dagger}$ 2016-2017

\begin{tabular}{|c|c|c|c|c|}
\hline Status & $\begin{array}{l}\text { Total weighted } \\
\%(95 \% \mathrm{Cl})\end{array}$ & $\begin{array}{l}\text { Mostly urban counties weighted } \\
\%(95 \% \mathrm{Cl})\end{array}$ & $\begin{array}{l}\text { Mostly or completely rural counties weighted } \\
\qquad \%(95 \% \mathrm{Cl})\end{array}$ & p-value ${ }^{\S}$ \\
\hline \multicolumn{5}{|l|}{ Ever tested for HIV } \\
\hline United States & $38.9(38.7-39.2)$ & $40.1(39.8-40.4)$ & $32.0(31.5-32.4)$ & $<0.001$ \\
\hline 50 local jurisdictions & $46.9(46.3-47.5)$ & $46.9(46.3-47.5)$ & N/A & $\mathrm{N} / \mathrm{A}$ \\
\hline Seven states & $35.5(35.0-36.0)$ & $37.2(36.6-37.8)$ & $32.1(31.3-32.9)$ & $<0.001$ \\
\hline \multicolumn{5}{|c|}{ Tested for HIV in the past year } \\
\hline United States & $10.1(9.9-10.2)$ & $10.6(10.4-10.8)$ & $6.7(6.4-7.0)$ & $<0.001$ \\
\hline 50 local jurisdictions & $14.5(14.0-14.9)$ & $14.5(14.0-14.9)$ & $\mathrm{N} / \mathrm{A}$ & $\mathrm{N} / \mathrm{A}$ \\
\hline Seven states & $9.3(8.9-9.6)$ & $10.1(9.7-10.5)$ & $7.6(7.2-8.1)$ & $<0.001$ \\
\hline \multicolumn{5}{|c|}{ Tested for HIV in the past year among those with reported HIV risk } \\
\hline United States & $29.2(27.9-30.6)$ & $30.2(28.8-31.8)$ & $20.9(17.7-24.4)$ & $<0.001$ \\
\hline 50 local jurisdictions & $34.3(31.3-37.3)$ & $34.3(31.3-37.3)$ & N/A & N/A \\
\hline Seven states & $26.2(23.4-29.3)$ & $29.0(25.5-32.8)$ & $18.4(14.5-23.2)$ & $<0.001$ \\
\hline
\end{tabular}

Abbreviations: $\mathrm{Cl}=$ confidence interval; $\mathrm{N} / \mathrm{A}=$ not applicable.

* Urban and rural classifications were derived from 2010 U.S. Census. Counties with $<50 \%$ of the population residing in areas defined as rural were classified as urban counties. Counties with $\geq 50 \%$ of the population residing in areas defined as rural were classified as rural counties.

† The 50 local jurisdictions (48 counties, the District of Columbia, and San Juan, Puerto Rico) accounted for the majority of new HIV diagnoses, and the seven states (Alabama, Arkansas, Kentucky, Mississippi, Missouri, Oklahoma, and South Carolina) experienced disproportionate occurrence of HIV in rural areas, as identified from HIV diagnoses made during 2016-2017 and reported to the National HIV Surveillance System through June 2018. Diagnosis data from 2017 were considered preliminary.

$\S$ Rao-Scott chi-square p-values compare testing estimates between mostly urban counties and mostly or completely rural counties. 
TABLE 2. Ever and past-year testing for human immunodeficiency virus (HIV) among adults aged $\geq 18$ years - Behavioral Risk Factor Surveillance System, 50 local jurisdictions and seven states,* 2016-2017

\begin{tabular}{|c|c|c|c|}
\hline Jurisdiction & No. of respondents ${ }^{\dagger}$ & $\begin{array}{l}\text { Ever tested for HIV weighted } \\
\qquad \%(95 \% \mathrm{Cl})\end{array}$ & $\begin{array}{l}\text { Tested in past year for HIV weighted } \\
\%(95 \% \mathrm{Cl})\end{array}$ \\
\hline \multicolumn{4}{|c|}{50 local jurisdictions that accounted for the majority of new HIV diagnoses } \\
\hline $\begin{array}{l}\text { Arizona } \\
\text { Maricopa County }\end{array}$ & 11,130 & $36.5(35.1-37.9)$ & $8.4(7.6-9.3)$ \\
\hline $\begin{array}{l}\text { California } \\
\text { Alameda County } \\
\text { Los Angeles County } \\
\text { Orange County } \\
\text { Riverside County } \\
\text { Sacramento County } \\
\text { San Bernardino County } \\
\text { San Diego County } \\
\text { San Francisco County }\end{array}$ & $\begin{array}{r}740 \\
3,479 \\
1,206 \\
920 \\
952 \\
859 \\
1,543 \\
442\end{array}$ & $\begin{array}{l}37.7(33.3-42.3) \\
43.6(41.3-45.9) \\
39.8(36.1-43.6) \\
39.6(35.7-43.7) \\
42.0(38.1-46.0) \\
43.0(38.8-47.2) \\
45.5(42.3-48.7) \\
51.8(45.3-58.3)\end{array}$ & $\begin{array}{r}8.1(5.8-11.2) \\
13.4(11.9-15.0) \\
10.9(8.7-13.6) \\
10.3(8.0-13.1) \\
9.1(7.1-11.7) \\
12.7(10.1-15.8) \\
14.3(12.1-16.8) \\
14.9(11.3-19.3)\end{array}$ \\
\hline District of Columbia & 7,125 & $70.7(69.2-72.1)$ & $26.4(25.0-27.8)$ \\
\hline $\begin{array}{l}\text { Florida } \\
\text { Broward County } \\
\text { Duval County } \\
\text { Hillsborough County } \\
\text { Miami-Dade County } \\
\text { Orange County } \\
\text { Palm Beach County } \\
\text { Pinellas County }\end{array}$ & $\begin{array}{r}923 \\
1,502 \\
1,148 \\
1,377 \\
1,301 \\
911 \\
890\end{array}$ & $\begin{array}{l}54.0(49.4-58.5) \\
57.0(52.9-61.0) \\
52.7(48.4-56.9) \\
56.7(52.4-60.9) \\
48.6(44.6-52.7) \\
45.5(40.9-50.1) \\
41.0(36.4-45.8)\end{array}$ & $\begin{array}{r}19.0(15.6-23.0) \\
20.3(16.7-24.4) \\
15.3(12.3-18.8) \\
18.5(15.2-22.3) \\
14.9(12.2-18.1) \\
11.1(8.4-14.4) \\
12.4(9.0-16.7)\end{array}$ \\
\hline $\begin{array}{l}\text { Georgia } \\
\text { Cobb County } \\
\text { DeKalb County } \\
\text { Fulton County } \\
\text { Gwinnett County }\end{array}$ & $\begin{array}{l}576 \\
603 \\
967 \\
563\end{array}$ & $\begin{array}{l}43.7(38.9-48.7) \\
57.1(52.2-61.9) \\
56.9(53.2-60.5) \\
43.2(38.4-48.2)\end{array}$ & $\begin{array}{r}10.1(7.4-13.6) \\
19.5(15.6-24.0) \\
19.7(16.8-23.1) \\
11.8(8.9-15.5)\end{array}$ \\
\hline $\begin{array}{l}\text { Illinois } \\
\text { Cook County }\end{array}$ & 3,807 & $41.3(39.3-43.2)$ & $13.5(12.2-14.9)$ \\
\hline $\begin{array}{l}\text { Indiana } \\
\text { Marion County }\end{array}$ & 3,248 & $45.4(42.9-47.9)$ & $13.0(11.2-14.9)$ \\
\hline $\begin{array}{l}\text { Louisiana } \\
\text { East Baton Rouge Parish } \\
\text { Orleans Parish }\end{array}$ & $\begin{array}{l}664 \\
423\end{array}$ & $\begin{array}{l}49.7(44.3-55.2) \\
58.2(51.7-64.4)\end{array}$ & $\begin{array}{l}17.0(13.2-21.6) \\
24.0(18.2-31.1)\end{array}$ \\
\hline $\begin{array}{l}\text { Maryland } \\
\text { Baltimore City } \\
\text { Montgomery County } \\
\text { Prince George's County }\end{array}$ & $\begin{array}{l}1,735 \\
3,366 \\
2,598\end{array}$ & $\begin{array}{l}62.4(59.2-65.6) \\
44.1(41.7-46.5) \\
56.3(53.4-59.1)\end{array}$ & $\begin{array}{r}25.3(22.3-28.6) \\
10.6(9.2-12.3) \\
22.4(20.1-24.9)\end{array}$ \\
\hline $\begin{array}{l}\text { Massachusetts } \\
\text { Suffolk County }\end{array}$ & 1,495 & $48.6(44.7-52.5)$ & $15.2(12.5-18.2)$ \\
\hline $\begin{array}{l}\text { Michigan } \\
\text { Wayne County }\end{array}$ & 2,906 & $45.3(43.1-47.5)$ & $14.1(12.5-15.8)$ \\
\hline $\begin{array}{l}\text { Nevada } \\
\text { Clark County } \\
\text { New Jersey } \\
\text { Essex County } \\
\text { Hudson County }\end{array}$ & $\begin{array}{r}2,770 \\
1,581 \\
905\end{array}$ & $\begin{array}{l}40.7(38.5-42.9) \\
55.0(51.0-59.0) \\
50.2(45.4-54.9)\end{array}$ & $\begin{array}{l}10.9(9.5-12.4) \\
17.3(14.4-20.6) \\
15.8(12.5-19.6)\end{array}$ \\
\hline $\begin{array}{l}\text { New York } \\
\text { Bronx County } \\
\text { Kings County } \\
\text { New York County } \\
\text { Queens County }\end{array}$ & $\begin{array}{l}1,094 \\
2,030 \\
1,782 \\
1,568\end{array}$ & $\begin{array}{l}70.0(66.4-73.4) \\
57.0(54.3-59.7) \\
60.0(57.0-62.9) \\
52.3(49.2-55.5)\end{array}$ & $\begin{array}{l}31.3(28.1-34.8) \\
21.6(19.4-23.9) \\
22.0(19.6-24.6) \\
18.0(15.7-20.6)\end{array}$ \\
\hline $\begin{array}{l}\text { North Carolina } \\
\text { Mecklenburg County }\end{array}$ & 753 & $47.1(42.9-51.3)$ & $13.5(10.8-16.8)$ \\
\hline $\begin{array}{l}\text { Ohio } \\
\text { Cuyahoga County } \\
\text { Franklin County } \\
\text { Hamilton County }\end{array}$ & $\begin{array}{r}1,172 \\
1,749 \\
912\end{array}$ & $\begin{array}{l}44.2(40.7-47.9) \\
42.3(39.4-45.1) \\
41.6(37.7-45.7)\end{array}$ & $\begin{array}{l}11.9(9.6-14.6) \\
10.1(8.5-12.1) \\
11.3(8.9-14.3)\end{array}$ \\
\hline $\begin{array}{l}\text { Pennsylvania } \\
\text { Philadelphia County }\end{array}$ & 1,399 & $57.5(54.2-60.7)$ & $21.4(18.8-24.3)$ \\
\hline
\end{tabular}

See table footnotes on next page 
Morbidity and Mortality Weekly Report

TABLE 2. (Continued) Ever and past-year testing for human immunodeficiency virus (HIV) among adults aged $\geq 18$ years - Behavioral Risk Factor Surveillance System, 50 local jurisdictions and seven states, ${ }^{*}$ 2016-2017

\begin{tabular}{|c|c|c|c|}
\hline Jurisdiction & No. of respondents ${ }^{\dagger}$ & $\begin{array}{l}\text { Ever tested for HIV weighted } \\
\qquad \%(95 \% \mathrm{Cl})\end{array}$ & $\begin{array}{c}\text { Tested in past year for HIV weighted } \\
\%(95 \% \mathrm{Cl})\end{array}$ \\
\hline $\begin{array}{l}\text { Puerto Rico } \\
\text { San Juan Municipio }\end{array}$ & 1,042 & $57.2(52.7-61.6)$ & $17.0(14.0-20.5)$ \\
\hline $\begin{array}{l}\text { Tennessee } \\
\text { Shelby County }\end{array}$ & 717 & $53.4(49.0-57.8)$ & $22.8(18.9-27.3)$ \\
\hline $\begin{array}{l}\text { Texas } \\
\text { Bexar County } \\
\text { Dallas County } \\
\text { Harris County } \\
\text { Tarrant County } \\
\text { Travis County }\end{array}$ & $\begin{array}{r}784 \\
623 \\
1,214 \\
740 \\
1,855\end{array}$ & $\begin{array}{l}45.1(39.9-50.5) \\
44.2(38.7-49.8) \\
45.9(41.9-50.0) \\
46.0(40.8-51.4) \\
50.2(46.2-54.2)\end{array}$ & $\begin{array}{r}13.7(10.2-18.1) \\
14.4(10.7-19.2) \\
13.2(10.8-16.2) \\
11.6(8.3-16.0) \\
12.3(9.9-15.3)\end{array}$ \\
\hline $\begin{array}{l}\text { Washington } \\
\text { King County }\end{array}$ & 6,101 & $39.4(37.9-40.9)$ & $8.4(7.5-9.3)$ \\
\hline Seven states with disp & e in rural counties & & \\
\hline $\begin{array}{l}\text { Alabama, total } \\
\text { Urban counties } \\
\text { Rural counties }\end{array}$ & $\begin{array}{r}12,098 \\
7,442 \\
4,656\end{array}$ & $\begin{array}{r}39.4(38.3-40.6) \\
40.8(39.4-42.3) \\
36.8(34.8-38.8)\end{array}$ & $\begin{array}{r}11.0(10.2-11.8) \\
12.1(11.1-13.2) \\
8.8(7.6-10.2)\end{array}$ \\
\hline $\begin{array}{l}\text { Arkansas, total } \\
\text { Urban counties } \\
\text { Rural counties }\end{array}$ & $\begin{array}{l}9,268 \\
5,206 \\
4,062\end{array}$ & $\begin{array}{r}33.7(31.9-35.6) \\
35.8(33.4-38.3) \\
30.9(28.3-33.6)\end{array}$ & $\begin{array}{r}9.1(7.9-10.4) \\
10.6(8.9-12.5) \\
7.1(5.7-8.8)\end{array}$ \\
\hline $\begin{array}{l}\text { Kentucky, total } \\
\text { Urban counties } \\
\text { Rural counties }\end{array}$ & $\begin{array}{r}16,937 \\
8,887 \\
8,050\end{array}$ & $\begin{array}{r}33.8(32.6-34.9) \\
36.3(34.7-38.0) \\
29.9(28.4-31.4)\end{array}$ & $\begin{array}{r}7.2(6.6-7.9) \\
8.0(7.1-9.0) \\
6.0(5.3-6.9)\end{array}$ \\
\hline $\begin{array}{l}\text { Mississippi, total } \\
\text { Urban counties } \\
\text { Rural counties }\end{array}$ & $\begin{array}{l}8,984 \\
4,207 \\
4,777\end{array}$ & $\begin{array}{r}40.2(38.7-41.7) \\
44.3(42.2-46.5) \\
35.4(33.4-37.4)\end{array}$ & $\begin{array}{r}12.7(11.6-13.9) \\
14.3(12.7-16.1) \\
10.9(9.5-12.4)\end{array}$ \\
\hline $\begin{array}{l}\text { Missouri, total } \\
\text { Urban counties } \\
\text { Rural counties }\end{array}$ & $\begin{array}{r}13,446 \\
9,031 \\
4,415\end{array}$ & $\begin{array}{r}34.3(33.1-35.5) \\
36.4(34.8-37.9) \\
29.1(27.1-31.3)\end{array}$ & $\begin{array}{r}8.3(7.5-9.1) \\
9.3(8.4-10.4) \\
5.6(4.5-6.8)\end{array}$ \\
\hline $\begin{array}{l}\text { Oklahoma, total } \\
\text { Urban counties } \\
\text { Rural counties }\end{array}$ & $\begin{array}{r}11,952 \\
7,365 \\
4,587\end{array}$ & $\begin{array}{r}29.7(28.6-30.9) \\
30.7(29.2-32.2) \\
27.8(26.0-29.7)\end{array}$ & $\begin{array}{r}6.8(6.2-7.6) \\
7.4(6.5-8.4) \\
5.7(4.8-6.9)\end{array}$ \\
\hline $\begin{array}{l}\text { South Carolina, total } \\
\text { Urban counties } \\
\text { Rural counties }\end{array}$ & $\begin{array}{r}19,983 \\
14,201 \\
5,782\end{array}$ & $\begin{array}{c}37.4(36.4-38.3) \\
37.7(36.5-38.8) \\
36.1(34.3-38.0)\end{array}$ & $\begin{array}{c}10.6(9.9-11.3) \\
10.5(9.8-11.4) \\
10.9(9.6-12.4)\end{array}$ \\
\hline
\end{tabular}

Abbreviation: $\mathrm{Cl}=$ confidence interval.

* Urban and rural classifications were derived from 2010 U.S. Census. Counties with $<50 \%$ of the population residing in areas defined as rural were classified as urban counties. Counties with $\geq 50 \%$ of the population residing in areas defined as rural were classified as rural counties. The 50 local jurisdictions ( 48 counties, the District of Columbia, and San Juan, Puerto Rico) accounted for the majority of new HIV diagnoses, and the seven states (Alabama, Arkansas, Kentucky, Mississippi, Missouri, Oklahoma, and South Carolina) experienced disproportionate occurrence of HIV in rural areas, as identified from HIV diagnoses made during 2016-2017 and reported to the National HIV Surveillance System through June 2018. Diagnosis data from 2017 were considered preliminary.

† Number of respondents with "yes" or "no" response to question about ever testing for HIV.

to fully implement HIV screening recommendations in the 57 jurisdictions that will serve as the initial geographic focus of the Ending the HIV Epidemic initiative. The observed variability in both ever and past-year testing by jurisdiction highlights the need for screening strategies that are tailored to local needs. BRFSS is likely the only annual survey with a sufficient sample size to provide jurisdiction-level estimates of HIV testing to monitor long-term progress toward increasing screening coverage in the United States.

HIV screening strategies will likely need to be locally tailored and novel to reach segments of the population that have not been reached by previous efforts. Examples of novel or promising approaches to increase access to HIV testing include routinizing HIV screening in health care settings, integrating HIV screening with sexual health screenings, scaling up partner notification and other strategies (using social network strategy ${ }^{\mathbb{S}}$ or mobile applications) that offer screening of the social and sexual networks of persons seeking HIV screening, promoting pharmacist-led screening 99 as well as screening in other alternative clinical settings such as urgent care, and mass

\footnotetext{
$\$ \$$ https://effectiveinterventions.cdc.gov/en/care-medication-adherence/group-4/ social-network-strategy-for-hiv-testing-recruitment.

99 https://effectiveinterventions.cdc.gov/en/hiv-testing/group-1/ hiv-testing-in-retail-pharmacies.
} 
FIGURE. Percentage of adults aged $\geq 18$ years ever tested for human immunodeficiency virus (HIV) infection and HIV diagnosis rate* among adults and adolescents aged $\geq 13$ years - Behavioral Risk Factor Surveillance System and National HIV Surveillance System (NHSS), 50 local jurisdictions accounting for the majority of new HIV diagnoses and seven states with disproportionate occurrence of HIV in rural areas, ${ }^{\dagger} 2016-2017 \S$

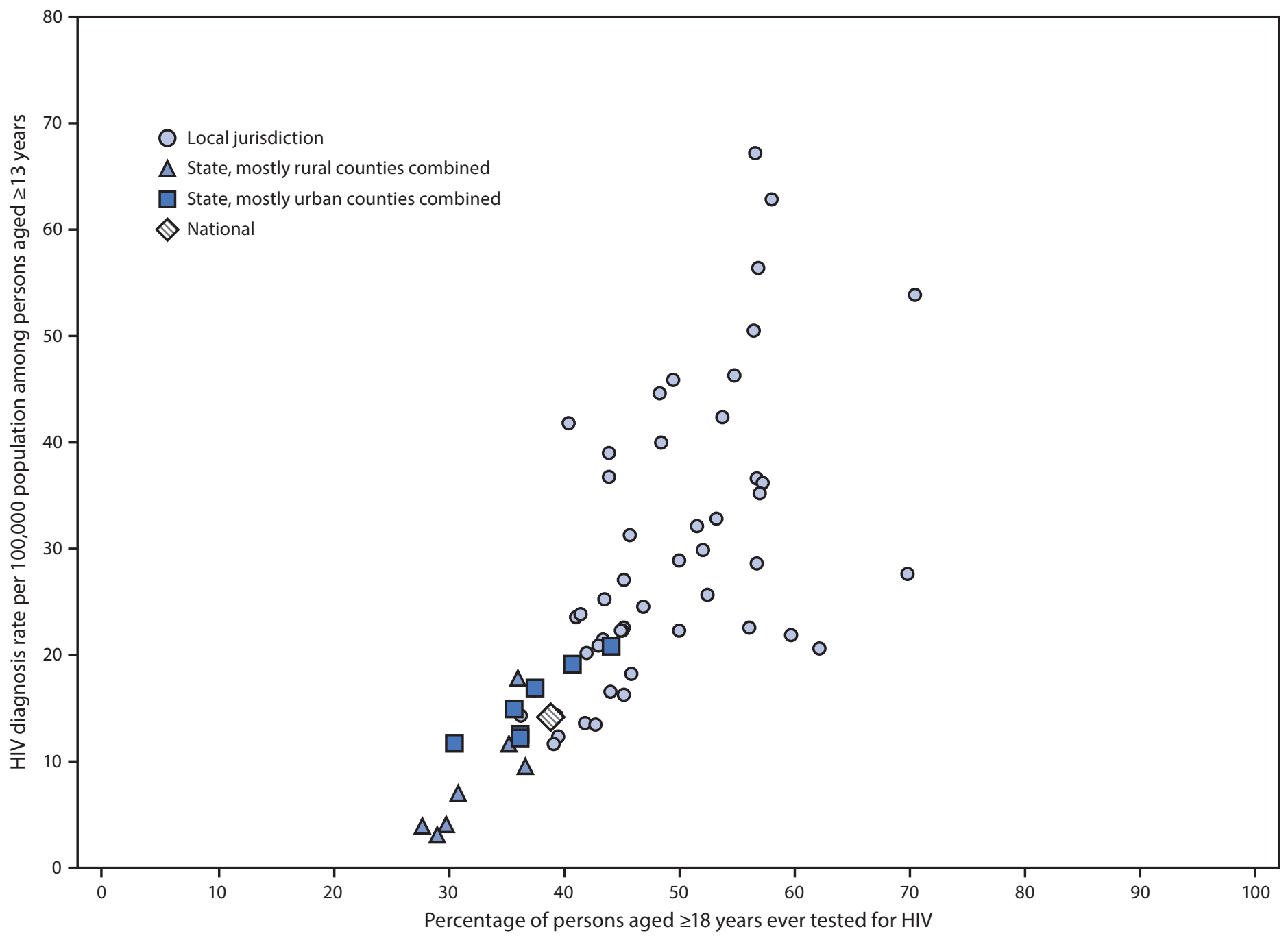

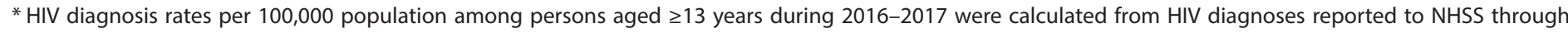
December 2018 and U.S. Census population estimates for 2016 and 2017.

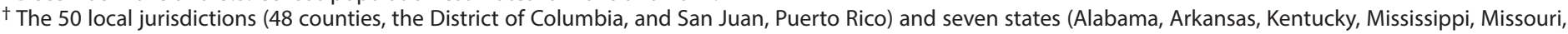

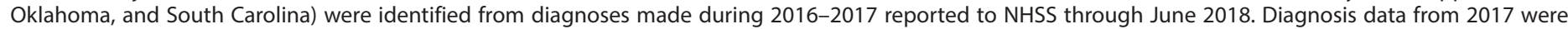
considered preliminary.

$\S$ Pearson's correlation coefficient $=0.71 ; p<0.01$.

distribution of HIV self-tests*** (6-10). Further efforts will be needed to identify which approaches are most effective in increasing access to HIV testing in various settings and jurisdictions with different baseline needs. Early diagnosis and effective treatment that suppresses HIV replication not only minimize immune system damage and reduce individual morbidity and mortality but also reduce the risk for transmission to others. ${ }^{\dagger \dagger}$ Delayed diagnosis limits these benefits.

\footnotetext{
*** https://www.cdc.gov/hiv/testing/hometests.html.

†† https://www.cdc.gov/hiv/risk/art/index.html.
}

HIV screening is a critical entry point to a range of HIV prevention and treatment options. For persons at ongoing risk for HIV infection exposure, annual screening also offers the opportunity to discuss options to reduce risk, including HIV preexposure prophylaxis. $\$ \$ \$ \$$

The findings in this report are subject to at least six limitations. First, because the proportion of respondents reporting recent HIV risk was small, testing percentages for this group could not be reported separately in the 57 jurisdictions. Second,

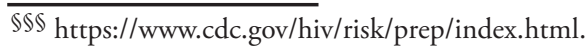




\section{Summary}

What is already known about this topic?

Rates of screening for human immunodeficiency virus (HIV) in the United States are low.

What is added by this report?

This analysis of national survey data found that $<40 \%$ of U.S. adults had ever been tested for HIV, and testing rates varied among jurisdictions comprising the initial focus of the Ending the HIV Epidemic initiative. Within these jurisdictions, rural areas had lower testing percentages and lower HIV diagnosis rates than did urban areas.

What are the implications for public health practice?

Novel HIV screening strategies tailored to meet local needs might be needed to reach segments of the population that have never been tested for HIV and achieve national goals to end the HIV epidemic in the United States.

self-reported data might be subject to social desirability and recall biases, which might have led to over- or underestimation of testing. Third, BRFSS response rates were low; however, the response rates are comparable with those of other national landline and cellular telephone surveys, and survey weights were designed to ensure generalizable findings. Fourth, the measure of HIV-related risk did not include every behavior that might increase risk for HIV infection, such as unprotected sex with a partner who is known to have HIV or whose HIV status is unknown. Fifth, the assessment of HIV diagnosis rates and HIV testing percentages relied on disparate age ranges ( $\geq 13$ years and $\geq 18$ years, respectively). Finally, this analysis included data from surveys conducted during 2016-2017 and HIV diagnoses that occurred during the same period. These are the most current data available for these measures but represent a delayed crosssection of the current state of HIV testing and diagnoses for 2019. To monitor progress toward national goals, closer to realtime reporting of select HIV testing activities might be needed.

HIV screening remains suboptimal for persons residing in the 57 jurisdictions that will constitute the initial geographic focus of the Ending the HIV Epidemic initiative. These data provide a baseline from which to measure changes in screening in these jurisdictions and other parts of the United States over time. To achieve national goals and end the HIV epidemic in the United States, innovative and novel screening approaches might be needed to reach segments of the population that have never been tested for HIV.

\section{Acknowledgment}

Kim Elmore, PhD, Division of HIV/AIDS Prevention, National Center for HIV/AIDS, Viral Hepatitis, STD, and TB Prevention, CDC.

Corresponding author: Marc A. Pitasi, mpitasi@cdc.gov, 404-639-6361.

${ }^{1}$ Division of HIV/AIDS Prevention, National Center for HIV/AIDS, Viral Hepatitis, STD, and TB Prevention, CDC.

All authors have completed and submitted the ICMJE form for disclosure of potential conflicts of interest. No potential conflicts of interest were disclosed.

\section{References}

1. Branson BM, Handsfield HH, Lampe MA, et al. Revised recommendations for HIV testing of adults, adolescents, and pregnant women in healthcare settings. MMWR Recomm Rep 2006;55(No. RR-14).

2. DiNenno EA, Prejean J, Irwin K, et al. Recommendations for HIV screening of gay, bisexual, and other men who have sex with menUnited States, 2017. MMWR Morb Mortal Wkly Rep 2017;66:830-2. https://doi.org/10.15585/mmwr.mm6631a3

3. Pitasi MA, Delaney KP, Oraka E, et al. Interval since last HIV test for men and women with recent risk for HIV infection-United States, 2006-2016. MMWR Morb Mortal Wkly Rep 2018;67:677-81. https:// doi.org/10.15585/mmwr.mm6724a2

4. Dailey AF, Hoots BE, Hall HI, et al. Vital signs: human immunodeficiency virus testing and diagnosis delays_-United States. MMWR Morb Mortal Wkly Rep 2017;66:1300-6. https://doi.org/10.15585/mmwr.mm6647e1

5. Fauci AS, Redfield RR, Sigounas G, Weahkee MD, Giroir BP. Ending the HIV epidemic: a plan for the United States. JAMA 2019;321:844-5. https://doi.org/10.1001/jama.2019.1343

6. Sullivan PS, Lyons MS, Czarnogorski M, Branson BM. Routine screening for HIV infection in medical care settings: a decade of progress and next opportunities. Public Health Rep 2016;131(Suppl 1):1-4. https://doi. org/10.1177/00333549161310S101

7. Golden MR, Katz DA, Dombrowski JC. Modernizing field services for human immunodeficiency virus and sexually transmitted infections in the United States. Sex Transm Dis 2017;44:599-607. https://doi. org/10.1097/OLQ.0000000000000652

8. Kachur R, Hall W, Coor A, Kinsey J, Collins D, Strona FV. The use of technology for sexually transmitted disease partner services in the United States: a structured review. Sex Transm Dis 2018;45:707-12. https:// doi.org/10.1097/OLQ.0000000000000864

9. Weidle PJ, Lecher S, Botts LW, et al. HIV testing in community pharmacies and retail clinics: a model to expand access to screening for HIV infection. J Am Pharm Assoc 2014;54:486-92. https://doi. org/10.1331/JAPhA.2014.14045

10. Katz DA, Golden MR, Hughes JP, Farquhar C, Stekler JD. HIV selftesting increases HIV testing frequency in high-risk men who have sex with men: a randomized controlled trial. J Acquir Immune Defic Syndr 2018;78:505-12. https://doi.org/10.1097/QAI.0000000000001709 